$$
\text { ilmiyat }
$$

Tokat IImiyat Dergisi | Tokat Journal of Ilmiyat

9/2 (Aralık | December 2021)

ISSN 2717-6134 | e-ISSN 2717-610X

\title{
Sosyal Medyada Yer Alan Dini İçerikler ve Din Eğitimi Üzerindeki Etkileri: Bir Alan Araştırması
}

Religious Content on Social Media and its Effects on Religious Education: A Field Study

\section{Fatma Dolunay ÖZTÜRK Aybiçe TOSUN}

\author{
Doktora Öğr., Eskişehir Osmangazi Dr. Öğr. Üyesi, Eskişehir Osmangazi \\ Üniversitesi Üniversitesi \\ Sosyal Bilimler Enstitüsü illahiyat Fakültesi \\ Din Eğitimi Bilim Dalı Din Eğitimi Bilim Dalı \\ Eskişehir|Türkiye Eskişehir|Türkiye \\ fdolunayozturk@hotmail.com atosun@ogu.edu.tr \\ orcid.org/0000-0003-0047-5586 orcid.org/0000-0002-6555-419X
}

\section{Makale Bilgisi | Article Information}

Makale Türü | Araştırma Makalesi Article Types | Research Article

Geliş Tarihi | 13 Ekim 2021 Received | 13 October 2021

Kabul Tarihi | 15 Aralık 2021 Accepted|15 December 2021

Yayın Tarihi | 30 Aralık 2021 Published | 30 December 2021

Bu makale, Sosyal Medyanın 12. Sınıf Öğ- This article, was produced from the master rencilerinin Dinî Bilgileri Üzerindeki Etkileri thesis Effects of Social Media On Religious

adlı yüksek lisans tezinden üretilmiştir. Knowledge of 12th Grade Students, Eskişe-

Eskişehir: Osmangazi Üniversitesi, 2021 hir: Osmangazi University, 2021.

\section{Atıf | Cite as}

Öztürk, Fatma Dolunay - Tosun, Aybiçe. "Sosyal Medyada Yer Alan Dini iç̧erikler ve Din Eğitimi Üzerindeki Etkileri: Bir Alan Araştırması [Religious Content on Social Media and its Effects on Religious Education: A Field Study]". Tokat IImiyat Dergisi | Tokat Journal of IImiyat 9/2 (Aralık | December 2021), 607-630. https://doi.org/10.51450/ilmiyat.1009036

\section{intihal | Plagiarism}

Bu makale, iTenticate aracılığıyla taranmış ve intihal içermediği teyit edilmiştir.

| This article, has been scanned by iThenticate and no plagiarism has been detected.

\section{Copyright $\odot$}

Published by Tokat Gaziosmanpaşa University Faculty of Islamic Sciences. Tokat | Turkey. https://dergipark.org.tr/ilmiyat

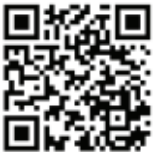




\title{
Religious Content on Social Media and its Effects on Religious Educa- tion: A Field Study
}

\begin{abstract}
Social media has become a tool that is most widely used in today's communication and interaction and its sphere of influence is expanding day by day. Social networks affect many areas in daily life such as politics, fashion, consumption, entertainment, advertising, economy and social movements. Social media, which has the power of reconstruction in social and cultural areas, has a structure that allows the individual to produce new identities and live in a second world. Social media, which is an alternative field of socialization, informs and guides the individual about religion, values, moral principles and interpersonal relations. At this point, education and religious education can be counted among the areas where the impact of social media is strong. Religious information in social media affects the individual as well as religious education practices. Although individuals' access to religious education has become easier today, the quality and content of education has become more complex with the diversity of sources which includes religious knowledge.
\end{abstract}

The aim of this research is to examine points of view of $12^{\text {th }}$ grade students about religious content and the characteristics of religious content on social media and the effects of social media sharing on the subject of Religious Culture and Moral Knowledge. In this study, which was carried out with the qualitative research method, focus group interviews were conducted with five groups of five people. During the focus group interviews, semi-structured interview questions were asked and the findings were analyzed by content analysis technique. From the interview data; the themes of the content of religious knowledge, the quality of religious content and the reflection of religious content in the Religious Culture and Moral Knowledge course were reached. In the theme of the content of religious knowledge, it has been concluded that there is a high probability that a religious post will appear on social media whether the participants follow it or not. In the theme of philosophical perspectives; it was revealed that encountering different beliefs offered the participants an opportunity to be informed and to compare these beliefs. In the interpretations about religion, it has been concluded that any subject in daily life becomes a material that can be interpreted under the umbrella of religion. In terms of othering, which is under the characteristics of religious content, the results consist of Islamophobia, othering through clothing and lifestyle, media bias and hate speech in social media. The difficulty of controlling the information in social media, the existence of information of unknown origin and conflicting information in terms of reliability are among the results achieved. From the findings on the misdirection of social media, it was concluded that the information in the social media may have a manipulative effect. The results about the reflection of religious content on Religious Culture and Moral Knowledge; it was concluded that some of the participants did not reflect the contents of the social media to the classroom, while some of them discussed these contents in the lessons. These discussions are aimed at making sense of the participants' knowledge, and the Religious Culture and Moral Knowledge course has a positive effect at this point.

The findings of the research revealed that the information about religion in social media affected $12^{\text {th }}$ grade students from points such as religion, religious life, marginalization, reaching the right religious information and verifying the information in the social media. At this point, it can be said that it is impossible to control the content in order to reach the correct information, and a mechanism is needed to confirm the information in social media. Religious Culture and Moral Knowledge course; can be considered as an area where correct religious knowledge over against the biased, wrong, marginalizing and exclusionary information and discourses in social media. 
In addition to this, opportunities should be created for students to become equipped with social media literacy.

Keywords: Religious Education, Subject of Religious Culture and Moral Knowledge, Religion in Social Media, Religious Knowledge, $12^{\text {th }}$ Grade Students.

\section{Sosyal Medyada Yer Alan Dini İçerikler ve Din Eğitimi Üzerindeki Etkileri: Bir Alan Araştırması}

Öz: Sosyal medya günümüz iletişim ve etkileşiminde en yaygın biçimde kullanılan ve etki alanı gün geçtikçe genişleyen bir araç haline gelmiştir. Sosyal ağlar günlük hayatta politika, moda, tüketim, eğlence, reklam, ekonomi ve toplumsal hareketler gibi pek çok alana etki etmektedir. Toplumsal ve kültürel alanlarda inşa gücü bulunan sosyal medya, bireyin yeni kimlikler üretip ikinci bir dünyada yaşamasına olanak tanıyan bir yapıya sahiptir. Alternatif bir sosyalleşme alanı olan sosyal medya; din, değerler, ahlakî ilkeler ve kişiler arası ilişkiler ile ilgili bireyi hem bilgilendirmekte hem de yönlendirmektedir. Bu noktada eğitim ve din eğitimi sosyal medyanın etkisinin güçlü olduğu alanlar arasında sayılabilir. Sosyal medyada yer alan dini bilgilerin bireyi etkilediği gibi din eğitimi uygulamalarını da etkilemektedir. Bugün bireylerin din eğitimine erişimi kolaylaşmış olsa da dini bilgiyle karşılaşılan kaynakların çeşitlenmesi ile birlikte eğitimin niteliği ve içeriği karmaşık bir hale gelmiştir.

$\mathrm{Bu}$ çalışmanın amacı 12. sınıf öğrencilerine göre, sosyal medyada yer alan din ile ilgili paylaşımları dini içerik, nitelik ve Din Kültürü ve Ahlak Bilgisi dersine etkileri bakımından incelemektir. Nitel araştırma yöntemi ile yürütülen bu çalışmada beşer kişiden oluşan beş grup ile odak grup görüşmeleri yapılmıştır. Odak grup görüşmeleri sırasında yarı- yapılandırılmış görüşme soruları sorulmuş ve elde edilen bulgular içerik analizi tekniği ile çözümlenmiştir. Görüşme verilerinden; dini bilginin içeriği, dini içeriğin niteliği ve dini içeriğin Din Kültürü ve Ahlak Bilgisi dersine yansıması temalarına ulaşılmıştır. Dinibilgininiç̧eriğitemasında sosyal ağlardaki dini paylaşımlar ile ilgili olarak katılımcılar takip etse de etmese de sosyal medyada karşılarına din ile ilgili bir paylaşımın çıkması ihtimalinin yüksek olduğu sonucuna ulaşılmıştır. Felsefi bakış açıları temasında ise farklı inançlarla karşılaşmanın katılımcıların hem bilgilenme hem de bu inançları kıyaslama olanağı sunduğu bilgisi ortaya çıkmıştır. Din ile ilgili yorumlarda ise gündelik hayattaki herhangi bir konunun din çatısı altında yorumlanabilecek bir malzeme haline gelişi ile ilgili sonuçlara ulaşılmıştır. Dini içeriğin niteliği altında yer alan ötekileştirmeye yönelik olarak sosyal medyada İslamofobi, giyim ve yaşam tarzı üzerinden ötekileştirme, medyanın yanlılığı ve nefret söylemlerine yönelik sonuçlar elde edilmiştir. Bu konu ile ilgili; sosyal medyadaki bilgilerin denetlenmesinin güçlüğü, kaynağı belli olmayan ve güvenirlik açısından çelişki yaşatan bilgilerin varlığı da ulaşılan sonuçlar arasındandır. Sosyal medyanın yanlış yönlendiriciliğine dair bulgulardan ise sosyal medyada yer alan bilgilerin manipüle edici etkisinin olabileceği yargısı ön plana çıkmıştır. Dini içeriğin Din Kültürü ve Ahlak Bilgisine yansımasına ilişkin elde edilen sonuçlar ise; bazı katılımcıların sosyal medyadaki içerikleri derse yansıtmadıkları, bazılarının ders ortamında bu içerikleri tartıştıkları sonucuna ulaşılmıştır. Söz konusu tartışmalar katılımcıların bilgilerini anlamlandırmaya yöneliktir ve Din Kültürü ve Ahlak bilgisi dersi bu noktada olumlu bir etkiye sahiptir.

Bu çalışma Eskişehir Osmangazi Üniversitesi Bilimsel Araştırma Projeleri Koordinasyon Birimi tarafından 202018A107 no'lu proje kapsamında desteklenmiștir. 
Araştırma bulguları sosyal medyada din ile ilgili yer alan bilgilerin 12 . Sınıf öğrencilerinin din, dini yaşam, ötekileştirme, doğru dini bilgiye ulaşma ve sosyal medyada yer alan bilgileri doğrulayabilme gibi noktalardan etkilediği ortaya çıkmıştır. Bu noktada doğru bilgiye ulaşabilmek için içerik kontrolü yapılmasının imkânsız olduğu ve denetlenemeyen bir alan olan sosyal medyada yer alan bilgilerin teyit edilebileceği bir mekânizmaya ihtiyaç duyulduğu söylenebilir. Din Kültürü ve Ahlak Bilgisi dersi sosyal medyada yer alan yanlı, yanlış, ötekileştirici ve dışlayıcı bilgi ve söylemler karşısında doğru dini bilgiye ulaşılabilecek bir alan olarak değerlendirilebilir. Bununla birlikte öğrencilerin sosyal medya okuryazarlığı ile ilgili donanımlı hale gelmeleri için firsatlar oluşturulması gerekmektedir.

Anahtar Kelimeler: Din Eğitimi, Din Kültürü ve Ahlak Bilgisi Dersi, Sosyal Medyada Din, Dini Bilgi, 12. Sınıf Öğrencileri.

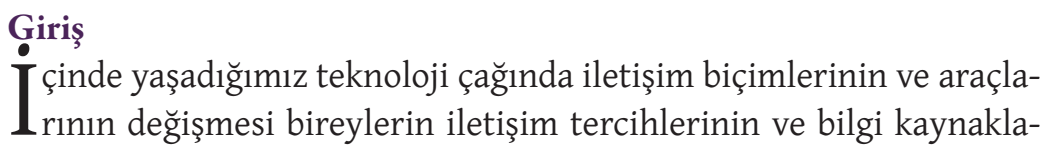
rının da farklılaşmasını beraberinde getirmektedir. İletişim ve sosyalleşme için kullanılan dijital ortamlar; haberleşme, gündemi takip etme ve bilgiye hızlı erişim gibi imkânlar sağlamaktadır. Dijital alanlardan birisi olan sosyal medya ise hızlı gelişimi ve güncellenebilir oluşunun yanında her kesimden insanın kolayca erişim sağlayabilmesi sayesinde bir aynı zamanda bir iletişim aracı olarak popülerlik kazanmaktadır.

On sekizinci yüzyılın ardından kitle iletişim araçlarının yaygınlaşmas1 ile eğitim-öğretim süreçlerine radyo ve televizyon gibi dijital kanallar aracılığıyla öğrenme imkânı eklenmiştir. Sonrasında dijital teknolojilerin sunduğu yeni imkânlarla birlikte çeşitli kitle iletişim kanalları işitsel ve görsel materyaller ile günümüz eğitim ve öğretim sürecinin ayrılmaz bir parçası haline gelmiştir. Eğitim araçlarının ve materyallerinin değişimi ve gelişimi ile birlikte öğrencilerin düşünüş ve algılayış biçimleri de dönüşüme uğramıştır. İletişim araçlarının sosyal ve bireysel hayattın ayrılmaz bir parçası olması bu araçların eğitimde kullanılmasını da kaçınılmaz hale getirmiștir. ${ }^{1}$ İnsanların iş birliği ve eğitimi üzerine odaklanan teknolojiler hızlı bir şekilde gelişmekte ve sayıları da artmaktadır ve sosyal medya ağları bu grubun bir parçası haline gelmektedir. Zira bireyler sosyal ağları sadece video, fotoğraf veya fikir paylaşımı için değil öğrenme ve öğretim deneyimlerini zenginleștirmek için de etkili şekilde kullanmaktadır. ${ }^{2}$ Örneğin öğrenciler sosyal medya platformlarında yer alan profiller ve fo-

1 Ayşe Zişan Furat, “Din Eğitimi Ekseninde Türkiye'de Medya ve Din Araştırmaları”, Medya ve Din Araştırmaları Dergisi 2/1 (Haziran 2019), 29-51.

2 Mehmet Fatih Öztürk - Mustafa Talas, "Sosyal Medya ve Eğitim Etkileşimi”, Zeitschrift für die Welt der Türken/ Journal of World of Turks 7/1 (2015), 102. 
rumlar üzerinden bilgi edinebilmekte ve video içerikler aracıllğıyla ile çeşitli bilgilere ulaşabilmektedir. Bu durum sosyal medyanın bir öğrenme ortamı olarak incelenmesini de beraberinde getirmektedir.

Sosyal medyada yer alan dini içeriklerin çeşitliliği bu alanda yer alan bilgilerin din eğitimi açısından değerlendirilmesini gerekli kılmaktadır. $\mathrm{Bu}$ durum, din eğitiminde dini bilginin kaynakları açısından sosyal medyanın da tartışmalara dahil edilmesi ve yeni tartışma alanlarının açılmasını beraberinde getirmektedir. Günlük hayatta önemli bir yere sahip olmaya başlayan internet, bireylerin dini inanç ve düşüncelerini dile getirdiği sıradan alanlardan birisi olmuştur. Bireyler kutsal olduğuna inandıkları gün, hafta, ay gibi zamanlarda birbirlerine sosyal medya aracıllı̆ı̆la mesaj göndermekte, çoğu zaman ihtiyaç duyduklarında dinî içerikli sayfaları ziyaret etmekte, dinî forumlara katılarak düşüncelerini ifade etmekte ve birbirleriyle dinî bilgi alışverişinde bulunabilmektedir. Bununla birlikte internet bireylere uygun teknolojiyi kullandıkları zaman hem kendilerini anlatma hem de ötekine ulaşabilme firsatı tanımaktadır.

İnternet ve sosyal medyanın sağladığı sesli, sanal ve görsel iletişimin yaygınlık kazanması bireylerdeki dini bilginin ve algının farklılaşmasına sebep olmaktadır. Bu farklılaşmalar dinin tanıtımında, dini tutum ve davranışlarda, dinin yaşanmasında kendini göstermektedir. Bu sebeple araştırmanın temel problemi "Sosyal medyada 12. sınıf öğrencilerinin karşılaştığı din ile ilgili içeriklerin niteliği nedir ve bu içeriklerin öğrencilere etkisi ve DKAB dersine yansımaları nelerdir?" şeklinde belirlenmiştir.

\section{Sosyal Medya ve Din}

\subsection{Sosyal Medya}

Sosyal medyanın birbirine benzeyen birçok tanımı vardır ve bu tanımlar alandaki çalışmalar geliştikçe yenilenmektedir. Web 2.0, sosyal ağ ya da sosyal iletişim siteleri olarak da ifade edilen bu alan, yeni kuşak internet uygulamalarını içermektedir. Sosyal medya, "kullanıcılara enformasyon, düşünce, ilgi ve bilgi paylaşım imkânı tanıyarak karşılıklı etkileşim yaratan çevrimiçi araçlar ve web siteleri için ortak kullanılan bir terimdir". ${ }^{3}$ Sosyal medya; kullanıcıların ağ teknolojilerini kullanarak etkileşimde bulunmasına imkân sağlayan uygulama, hizmet ve araçların tümüne verilen isimdir. ${ }^{4}$ Başka bir tanıma göre sosyal medya mekân ve

Aslı Yağmurlu, “Kamu Yönetiminde Halkla İlişkiler ve Sosyal Medya”, Selçuk İletişim 1/7 (2011), 5-15.

4 Danah Boyd - Nicole B. Ellison, "Social Network Sites: Definition, History, and Scholarship", Journal of Computer-Mediated Communication 13 (2008), 210-230, akt. Esra Şişman Eren, "Sosyal Medya Kullanım Amaçları Ölçeğinin Geliştirilmesi ve Bazı Kişisel Değişkenlere Göre İncelen- 
zaman sınırlaması olmayan (mobil tabanlı), tartışmanın, paylaşımın esas olduğu iletişim şeklidir. ${ }^{5}$ Bu tanımlar ışı̆̆ında sosyal medya için bireylerin farklı kimlikler üretebildiği, aktif bir iletişim içinde bulunabildiği, kendini gerçekleştirebildiği, aynı zamanda bireyin düşünceleriyle etkilediği ve başkalarının etkisi altında kaldığı, başka bireyler hakkında görüş ve bilgi edinebildiği, sınırların ötesine geçebildiği ve dünyayı küçük bir yer haline getirebildiği soyut sosyal bir alan olduğu söylenebilir.

İnternet ve sosyal ağlar bireylerin kendilerine çeşitli kimlikler üretebildikleri ikinci bir dünya haline bürünmüştür. Ürettikleri biçim ve kimliklerle bireyler sosyal medyanın da içinde yer aldığı bu sanal dünyada kendilerini gerçekmiş gibi yaşanılan bir çevrede bulmaktadır. ${ }^{6}$ Yaşamda yer alan ilişkiler sosyal medya aracıllğıyla oluşturulan bu sanal gerçekliğe aktarılmaktadır. İletişimin sanal bir hal alması Facebook, WhatsApp, blog, Twitter vb. sosyal medya ağları vasıtasılla gerçekleşmekte, ${ }^{7}$ teknolojinin bireysel ve toplumsal hayata etkisi ile birlikte internet ve buna bağlı olarak sosyal medya, genellikle genç nesle yeni bilgi, değer, beceri ve tutum aşılamaktadır. ${ }^{8}$ Bu gerçeklikten yola çıkıldığında bireyler bilgi, haber ve belge paylaşımına ilave olarak daha fazla etkileşim ve romantik ilişkiler kurabilmekte, gruplara dahil olabilmekte, başka bireyleri takip ederken pek çok kişisel duygu ve aktiviteleri bu sanal ağlar üzerinden yaşayabilmektedir. ${ }^{9}$

Sosyal medyanın toplumsal ve kültürel alanlarda inşa gücü bulunmaktadır. Belirli ideolojileri inşa ederken toplumda yer alan bireyler arasındaki sınıfsal farklılıkların ve bireylerin yaşamındaki çelişkilerin üzerini örtmekte ve tüketim, moda, eğlence, yaşam biçimi gibi ile ilgili yeni anlamlar oluşturmaktadır. Sosyal medya, toplumdaki bireyleri bir bütün olarak ele alıp açıklamak yerine tüketim, gençlik, erkeklik, kadınlık ve eğlence gibi farklı alanlar oluşturmakta ve bu farklı alanlar çok sayıda sosyal medya platformlarında kendine yer bulmaktadır. Günümüzde etkile-

mesi”, Hacettepe Üniversitesi Eğitim Fakültesi Dergisi 29/4 (2014), 231.

5 Z. Beril Vural Akıncı - Mikail Bat, "Yeni Bir İletişim Ortamı Olarak Sosyal Medya: Ege Üniversitesi İletişim Fakültesine Yönelik Bir Araştırma”, Journal of Yasar University 5/20 (2010), 3351.

6 Nurettin Güz - Ceren Yegen, “Ölü Canlar'dan Instagram'a: Kimlik ve Statü Sahibi Olmanın Allomorfizmi Üzerine”, İletişim Kuram ve Araştırma Dergisi 45 (2017), 109.

İpek Sucu, "Sosyal Medya Oyunlarında Gerçeklik Olgusunun Yön Değiştirmesi: Smeet Oyunu Örneği”, Gümüşhane Üniversitesi İletişim Fakültesi Dergisi 3 (Mart 2012), 64.

8 Vahap Özpolat, "Postmodern Bir Sosyalleşme Mecrası Olarak Sosyal Medya ve Gençlik”, Gençlik ve Kültürel Mirasımız, Uluslararası Kongre II, ed. Bekir Şişman- Muhittin Düzenli, (Ankara: Gençlik ve Spor Bakanlığı, 2014), 48-50.

9 Tara Marshall vd., "Attachment styles as predictors of Facebook-related jealousy and surveillance in romantic relationships", Personal Relationships 20 (2013), akt. Sefer Kalaman - Fatih Çelik, “Türkiye'deki Evli Bireylerin Sosyalm Medya Kullanımlarının Evlilikleri Üzerine Etkisi: Nitel Bir Araştırma”, Uluslararası Toplum Araştırmaları Dergisi 13/19 (Eylül 2019), 428. 
şim, iletişim, iş hayatı, yeni nesil öğrenme gibi pek çok alanda kullanılan sosyal medyanın popülerliği giderek artmaktadır.

\subsection{Sosyal Medya, Eğitim ve Din Eğitimi}

Bilgisayarların ve buna bağlı olarak internetin eğitimde kullanılması, eğitim sistemini daha etkin bir noktaya ulaştırmış ve önemli gelişmeleri beraberinde getirmiştir. Bu gelişmeler eğitimde geleneksel yöntemlerin yerine yeni gelişmelere açık bir eğitim yaklaşımına kapı aralamıştır. Dijital ortamlar başlarda sadece araştırma-inceleme, tarama ve kaynaklara ulaşım noktasında yararlıyken sosyal medya günümüzde bir eğitim ortamı haline gelmiştir. Bu açıdan bakıldığında sosyal medya eğitimdeki bazı gereksinimleri karşılamanın yanında eğitimde çeşitliliği de sağlamaktadır. ${ }^{10}$

Bilişim sistemlerindeki gelişim ve değişim, eğitim öğretimi okul s1nırlarından dışarı çıkarmakta ve her an her yerde eğitime ulaşım imkânı sağlamaktadır. ${ }^{11} \mathrm{Bu}$ açıdan bir eğitim mecrası olarak değerlendirilebilecek olan sosyal medya öğretmen öğrenci etkileşimini farklı boyutlara taşımasıyla bir iletişim olarak görülebilecek eğitim uygulamalarının zamansal ve mekânsal sınırlarını esnetmiştir. Ĕgitim materyali olarak kabul edilen sosyal medya araçlarının çeşitli problemli alanlar barındırmasına karşın faydaları da bulunmaktadır. Bu faydalar arasında sosyal destek ve bağlanabilirlik, işbirlikçi keyif ve paylaşımı, içerik oluşturma yer almaktadır. ${ }^{12}$ Günümüz teknoloji çağında sosyal medya araçlarının kullanılması Z kuşağı açısından ele alındığında eğitimin bu alanda değişimi ve gelişimine yönelik yeni yaklaşımların oluşturulmasını zorunlu kılmaktadır. Bu noktada sosyal medyanın doğru, verimli ve etkin bir şekilde kullanımı için sosyal medya okur-yazarlığı önemli bir konuma gelmiştir.

Sosyal medya kullanımının yaygınlaşması ile birlikte bireysel yaşamda ve sosyal hayatta ortaya çıan değişimlerin bireyleri etkisi altında bıraktığı alanlardan biri dindir ve ahlaki değerlerdir. Bireylerin güven, mutluluk ve huzur içinde hayatlarını sürdürmelerini sağlayan önemli etkenlerden olan ahlaki ilkeler barış ve huzurun varlığı açısından gereklilik arz etmektedir. Bireyin biyolojik, sosyal, psikolojik gelişimiyle paralel olarak şekillenen ahlaki gelişimin bireyin etkileşim haline bulunduğu alanlarda etkilenmesi kaçınılmazdır. Ahlakın sağlıklı şekilde gelişimi için bireylerin

10 E. Pınar Uça Güneş, “Toplumsal Değişim, Teknoloji ve Eğitim İlişkisinde Sosyal Ağların Yeri”, Açıköğretim Uygulamaları ve Araştırmaları Dergisi Eskişehir 2/2 (2016), 196-197.

11 Mehmet Şişman, "Eğitim Bilimine Giriş", (Ankara: Pegem Akademi, 2013), 338.

${ }^{12}$ Nebiye Konuk - Selime Güntaş, "Sosyal Medya Kullanımı Eğitimi ve Bir Eğitim Aracı Olarak Sosyal Medya Kullanımı”, International Journal Entrepreneurship and Management Inquiries (Journal EMI) Dergisi 3/4 (Mart 2019), 6-7. 
toplumdaki beklenti ve istekleri de dikkate alması gerekir. Sosyal medya da birey ve toplum üzerinde etkili olan, onları şekillendiren mecralardandır. Bu nedenle sosyal medyada da ahlaki ilkelere uygun davranılması bir gerekliliktir.

İnsan eylemde bulunan bir varlık olduğundan onun bütün eylemleri bir değer ile alakalıdır. O halde değerleri; insanın eylemlerini belirleyen ilke ya da ilkeler olarak tanımlamak mümkündür. Değerler insanların eylemleri ve eylemlerinin altında yatan gerçek ile bağlantılıdır. Bu nedenle insanın değer ile bağlantılı olmayan herhangi bir davranışından bahsedilemez. ${ }^{13}$ İnsanın yer aldığı bir mecra olması sebebiyle sosyal medyada da değerlerin ve davranışların varlığından söz edilebilir. İnsan iyi ve kötünün ayrımını yapabilecek özelliğe sahiptir ve iyi olarak kabullendiklerine bir değer verir. Bu değerlerle yaşayıp onları koruyup geleceğe aktarmak için çabalar. ${ }^{14}$

Sosyal medyanın değerler üzerinde de olumlu ve olumsuz etkileri bulunmakla birlikte ${ }^{15}$ çoğunlukla değerleri olumsuz şekilde etkilediği görüşü kabul görmektedir. Bunun nedeni olarak ise sosyal medya kullanımının değerleri yozlaştırması gösterilmektedir. Sosyal medyada bireyler kendilerinde olmayan özellikleri varmış gibi yansıtabilmekte, küfürlü ve argo kelimelerle karşılaşabilmekte ve mahremiyetlerini paylaşabilmektedir. Sosyal medyada yer alan olumsuzluklara yalan haber ve iftira, siber zorbalık, gösteriş ve riya, uygun olmayan içeriklere erişim ve teşhir bunlara örnek olarak gösterilebilir. ${ }^{16}$

Sosyal medya değerlerin şekillenmesi ile ilgili bir takım rollere sahiptir. Bunlardan ilki, sosyal medya bağımlılı̆̆ının bireylerin yaşamlarındaki bazı değerleri ihmal etmesine neden olmasıdır. Diğer rolü ise bireylerin yaptıkları ve maruz kaldıkları paylaşımlar aracılığıyla değerlerin yaşama yansımasındaki değişimlerdir. Örneğin bazı durumlarda sosyal medyada yer alan yardımseverlik günlük yaşantıya yansımamaktayken bazen bunun zıttı bir durum da yaşanabilmekte ve görülen bir içerik sayesinde gerçek hayatta daha yardımsever olunabilmektedir. ${ }^{17} \mathrm{Bu}$ durum değerle-

${ }^{13}$ Enver Uysal, “Değerler Üzerine Bazı Düşünceler ve Bir Erdem Tasnifi Denemesi: İnsanî Erdemler-İslâmî Erdemler”, Uludağ Üniversitesi İlahiyat Fakültesi 12/1 (2003), 51-69.

${ }^{14}$ Selahattin Parladır, "Din Eğitiminde Hedefler", Dokuz Eylül Üniversitesi İlahiyat Fakültesi 9 (1995), 79-102.

15 Süleyman Gümrükçüoğlu, Din Eğitiminin Sosyal Medya Kullanımına Etkisi (Ankara: Nobel Bilimsel Eserler, 2020), 74.

${ }^{16}$ Mehmet Haberli, "Sosyal Medyada Dini İnanç ve Ahlaki Değerlerin Dejenerasyonu Üzerine Bir Değerlendirme”, I. Uluslararası İnsan ve Toplum Bilimleri Araştırmaları Kongresi, (Balıkesir: Bandırma On Yedi Eylül Üniversitesi, 2018), 644-647.

17 Yakup Ayaydın - Hatice Yıldız Ayaydın, "Sosyal Medyanın Değer Oluşturma Sürecindeki Rolünün Öğrenci Görüşleriyle İncelenmesi”, Değerler Eğitimi Dergisi 16/35 (Haziran 2018), 59-60. 
rin sosyal medyaya yansımasının bireylerin davranışlarını olumlu etkileyebileceği gibi bazen bu durumun hiçbir etkisinin olmadığ sonucuna da ulaştırmaktadır. Sosyal medyanın eğitim açısında olumlu ve olumsuz özellikleri tabloda (Tablo 1) gösterildiği gibi sıralanabilir.

Tablo 1: Sosyal Medyanın Eğitim Açısından Olumlu ve Olumsuz Etkileri

\begin{tabular}{ll}
\hline $\begin{array}{l}\text { Sosyal Medyanın Eğitim ile İlgili } \\
\text { Olumsuz Etkileri }\end{array}$ & $\begin{array}{l}\text { Sosyal Medyanın Eğitim ile İlgili Olumlu } \\
\text { Etkileri }\end{array}$ \\
\hline Değerlerin ihmal edilmesi & $\begin{array}{l}\text { Olumlu içeriklerin günlük yaşama } \\
\text { yansıyabilmesi }\end{array}$ \\
\hline Değerler yozlaşması & $\begin{array}{l}\text { Eğitim materyallerine ulaşımın kolaylığı } \\
\text { ve çeşitliliği }\end{array}$ \\
\hline $\begin{array}{l}\text { Uygun olmayan bir dille iletişime } \\
\text { imkânı vermesi }\end{array}$ & Yeni bilgi, değer ve tutumlar öğrenebilme \\
\hline Mahremiyeti ihlal etmesi & $\begin{array}{l}\text { Çeşitli kişilerle etkileşim kurup birbirleri- } \\
\text { yle öğrenme firsatı sunması }\end{array}$ \\
\hline $\begin{array}{l}\text { Karşılaşılan bilginin değerini ölçmek } \\
\text { zordur }\end{array}$ & \begin{tabular}{l} 
Öğrenme deneyimlerini geliştirmesi \\
\hline
\end{tabular}
\end{tabular}

Sosyal medyanın doğru bir şekilde kullanımı bireylerin değerlere uygun davranışlarda bulunması ve değerlerin ihlal edilmemesi bakımından önemlidir. Değerlere uygun davranışlarda bulunabilmek için değerleri yaşamın her alanında önemsemek gerekir. Bu açıdan din eğitimi, ahlak ve değerlerin bireylere aşılanmasında önemli bir role sahiptir.

\section{Yöntem}

Araştırmanın amacı 12. sınıf öğrencilerinin sosyal medyada karşılaştıkları dinî içerikleri ve bunlardan nasıl etkilendiklerini ortaya çıkarmaktır. Bu amaç doğrultusunda araştırma soruları şu şekilde belirlenmiştir:

1. Sosyal medya platformlarında öğrencilerin karşılaştıkları dini içerikler nelerdir?

2.Sosyal medyada öğrencilerin karşılaştıkları dini içeriklerin niteliği nedir?

3. Sosyal medyadaki dini içeriklerin DKAB dersine yansımaları nedir?

$\mathrm{Bu}$ çalışma nitel araştırma yöntemi esas alınarak hazırlanmıştır. Nitel araştırmada amaç; görüşme, gözlem ve doküman analizi gibi veri toplama metotlarını kullanarak sosyal olgular hakkında incelemeler yapmak, analiz etmek ve anlamak gibi süreçleri içerir. ${ }^{18}$ Araştırma deseni olarak

${ }^{18}$ Ali Yıldırım - Hasan Şimşek, Sosyal Bilimlerde Nitel Araştırma Yöntemleri (Ankara: Seçkin Yayıncllik, 2008), 39. 
durum çalışması belirlenmiştir. Durum çalışması nitel araştırmalarda kullanılan yaygın yöntemlerden biridir. Nitel araştırmalarda durum çalışmasının en büyük özelliği bir veya birkaç durumun bütüncül bir yaklaşımla derinliğine araştırılmasıdır. Araştırılan duruma bireyler, süreçler, olaylar ve ortamın nasıl bir etkide bulunduğuna ve bundan nasıl etkilendiğine odaklanilır ${ }^{19}$.

Araştırmanın çalışma grubu ölçüt örnekleme yöntemi ile seçilmiştir. Çalışma grubu; 4. sınıftan 12. Sınıfa kadar 8 yıl boyunca Din Kültürü ve Ahlak Bilgisi dersi almış ve sosyal medya platformlarını aktif bir biçimde kullanan öğrencilerinden oluşan 25 kişilik 12. sınıf öğrencilerinden oluşmaktadır. Çalışma grubu beşer kişilik gruplar halinde yarı yapılandııılmış görüşme soruları ile odak grup görüşmelerine alınmıştır. Öğrencilerin izni ile görüşmeler ses kayıt cihazı ile kaydedilmiş ve daha sonra kayıtlar dijital ortamda metinleștirilmiştir. Veriler içerik analizi tekniklerinden biri olan değerlendirici ve kategorizel analiz teknikleri ${ }^{20}$ kullanılarak analiz edilmiştir. İçerik analizinde veriler genellikle; verilerin kodlanması, temaların bulunması, verilerin kodlara ve temalara göre düzenlenmesi, bulguların tanımlanması ve yorumlanması şeklinde genel başlıklar altında analiz edilmektedir. ${ }^{21}$ Araştıranın kodlama sürecinde, kodlama türlerinden biri olan ve gündelik dilde "faydacı kodlama" olarak da bilinen yapısal kodlama kullanılmıştır. Yapısal kodlama çoklu ve yarı- yapılandırılmış görüşmeler için uygun bir kodlama türüdür. ${ }^{22}$ Araştırmanın güvenirlik hesaplaması için Miles ve Huberman'ın “Güvenirlik = Görüş Birliği x 100/Görüş birliği+ Görüş ayrıllı̆ı" formülü kullanılmıştır. ${ }^{23}$ Araştırmada uzman görüşü alınmış, görüş birliği ve görüş ayrılıkları hesaplanmıştır. Bu hesaplamanın sonucunda \%88,88 güvenirlik ortalamasına ulaşılmıştır.

\section{Bulgular ve Tartışma}

Araştırma sonucunda ulaşılan bulgular; öğrencilerin sosyal medyada karşılaştıkları dini bilgilerin içeriği, karşılaşılan dini bilgilerin niteliği ve son olarak sosyal medyada karşılaşılan dini bilgilerin Din Kültürü ve Ahlak Bilgisi dersine yansımaları temaları altında toplanmıştır.

19 Corrine Glesne, Nitel Araştırmaya Giriş, çev. Ali Ersoy- Pelin Yalçınoğlu (Ankara: Anı Yayıncılık, 2012), 30.

${ }^{20}$ Nuri Bilgin, Sosyal Bilimlerde İçerik Analizi Teknikler ve Örnek Çalışmalar (Ankara: Siyasal Kitabevi, 2006), 11-14.

${ }^{21}$ Bilgin, Sosyal Bilimlerde İçerik Analizi Teknikler ve Örnek Çalışmalar, 11-14.

${ }^{22}$ Johnny Saldana, Nitel Araştırmacılar İçin Kodlama El Kitabı, çev. Aysel Tüfekçi Akcan-Süleyman Nihad Şad, (Ankara: Pegem Yayınları, 2019), 98.

${ }^{23}$ Matthew B. Miles - A. Michael Huberman, Nitel Veri Analizi, çev. Sadegül Akbaba Altun - Ali Ersoy, (Ankara: Pegem Akademi, 2016), 64. 


\subsection{Dinî Bilginin İçeriği ile İlgili Bulgular}

Katılımcıların sosyal medyada karşılaşılan dini bilgilerin içeriği ile ilgili görüşleri; sosyal ağlarda dini paylaşımlar, felsefi bakış açıları, özel hayatta din ve din ile ilgili yorumlar temaları altında toplanmıştır.

\subsubsection{Sosyal Ağlarda Dinî Paylaşımlar}

Katılımcılar sosyal medyada karşılaştıkları bilgilerden bir kısmını dini içerikli bilgi olarak kategorize etmektedir. K10: "Ben genel anlamda sosyal medyada dinî içerikli şeyler... görmüyorum ama Türkiye'de genellikle kendine \%99'u... Müslümanım dediği için İslami postlar daha çok öne çıkıyor." şeklinde belirtmiştir. Dini paylaşımlarla ilgili K17: "Ben daha çok böyle ayet veya hadisler. Ne kadar takip etmesem de karşıma çıkıyor ilginç bir şekilde." sözleriyle dile getirmiştir. Sosyal medyada karşılaşılan dinî içeriklerden biri Cuma mesajlarıdır. Katılımcı K24: “... ya da eminim yani herkes her cuma hayırlı cumalar yazısıyla karşılaşıyordur. Ben de karşılaşıyorum." sözleriyle belirtmiştir. Aynı katılımcı hadislere rastladığını "En son Hz. Muhammed (s.a.v.)'in bir sözünü görmüştüm. Hadisini görmüştüm.” şeklinde belirtmiştir.

Alan yazında yer alan çalışmalara bakıldığında; Facebook'taki her üç kullanıcıdan biri dini paylaşımda bulunduğ $u^{24}$, dini içerikleri ve mizahi olarak yer alabildiği ve mizahın saldırganlık içerdiğ $i^{25}$, ayet ve hadis paylaşımlarıyla sıklıkla karşılaşıldığı ${ }^{26}$ görülmektedir. Araştırmaya katılan öğrencilerin de takip ettikleri alanlar ne olursa olsun din ile ilgili paylaşımlarla karşılaştıkları anlaşılmaktadır. Bu noktada takip edilen hesaplar dini olsun olmasın din ile ilgili bir paylaşımla karşılaşma olasılığının yüksek olmasının sosyal medyanın gençlerin din bilgileri üzerinde bir etki alanı oluşturabileceği düşünülebilir.

\subsubsection{Felsefi Bakış Açıları}

Katılımcılar İslam dini ile ilgili paylaşımlarla birlikte farklı inanma biçimleri ile ilgili bilgilere de sosyal medya aracılı̆̆ıyla ulaşabilmektedirler. Katılımcı K6: “...Onun dışında satanizmle alakalı takip ettiğim ve agnostisizmle ateizmle ilgili takip ettiğim sayfalar da var." sözleriyle belirtmiştir. Sosyal medyadaki felsefî görüşlerin varlığını katılımcı K20: “...Twitter'da

${ }^{24}$ Gamze Gezginci - Şevki Işıklı, “Dindar Facebook Etkisi: Türk Kullanıcılar Üzerine Bir Analiz”, Medya ve Din Araştırmaları Dergisi 1/1 (2018), 111-133.

${ }^{25}$ Asım Yapıcı - Yusuf Emre, "Mizah Anlayışı İle Dindarlığın Farklı Görüntüleri Arasındaki İlişkiler Üzerine Bir Araştırma”, Bilimname XL (Aralık 2019), 43-46.

${ }^{26}$ Recep Emin Gül, “Sosyal Medyada Hadis Kullanımı -Facebook ve Twitter Özelinde-“, Yüzüncü Yll Üniversitesi Sosyal Bilimler Enstitüsü Dergisi 30 (2016), 167-178. 
böyle deizmle ilgili bir şey takip ettiğimi hatırlıyorum... Ve kendilerini olabildiğince böyle şey göstermeye çalışıyorlar, nasıl denir kusursuz, mükemmel hani evet gerçekten ikon hani nasıl denir böyle ilham alınası bir şekil... Evet insanlar kendilerini göstermek için deist olabiliyorlar. Hani ben deistim işte havalıyım, beni örnek alın, güzel, değil mi yani?" şeklinde dile getirmiştir.

Farklı dini bakış açılarıyla karşılaşmak gençlerin hem farklılıklarla ilgili bilgi düzeyini artırmakta hem de farklı inançları kıyaslamak için bir fırsat sunmaktadır. Bununla birlikte bu tür inançlarla ilgili en doğru ve güvenilir bilgiye ulaşmak ya da bilgilerin güvenirliğini tespit edebilmek için doğru bilgi kaynaklarına ihtiyaç duyulmaktadır. Aksi takdirde farklılıklarla ilgili algılar yanlış yönlendirilmeye açıktır.

\subsection{3. Özel Hayatta Din}

Katılımcılar İslam dini ya da başka dini oluşumlarla birlikte bireylerin kendi dindarlıkları ile ilgili bilgilere de sosyal medya aracıllı̆ıyla ulaşmaktadırlar. Sosyal medyada muhafazakâr bireylerin bulunduğuna yönelik olarak katılımcı K8: "Benim de karşıma geliyor doğrusunu söylemek gerekirse Instagram'da olsun Twitter'da olsun... Özellikle hani son ylllarda mesela Twitter mecrasında özellikle biraz daha böyle alışık olduğumuz Türk tipi muhafazakâr tipten biraz daha kayış olduğunu gözlemliyorum ben insanlara böyle mahremiyetten biraz daha taviz verdiği ya da bazı şeyler konusunda artık geri çekilme mekanizmalarının yavaş olduğu paylaşımlar oluyor. Mesela görüşlerini çok açık belirtiyorlar. Onun dışında bunun ta diğer tarafta da aksini görüyorum tabii ki de." şeklinde belirtmiştir. Benzer açıdan katılımcı K6: "Genel olarak sosyal medyada gördügü̈m içerikteki durumlar yani şu an daha çok dinî olan şeylerden ziyade etraftaki insanların muhafazakâr tipler veya ailelerinden maruz kaldıkları muhafazakâr baskıdan veya maruz kaldıkları tavırlardan kurtulup sosyal medyada özgürce başka insanlara ne kadar sıkıldıklarını bunaldıklarını açılayabildiklerini görüyorum." sözlerini dile getirmiştir. Katılımcıların sosyal medyayı dini bakış açılarının özgürce paylaşıldığı bir alan olarak gözlemledikleri görülmektedir. Paylaşım yapan kişinin kimliğinin belirsiz olması paylaşılan içeriklerin de sosyal baskılardan uzak bir biçimde şekillenebilmesine olanak tanımaktadır. Bu noktada sosyal medyanın gerçek sosyal ortamlara güçlü bir alternatif olarak gençlerin bilgi ve duygu dünyasını şekillendirme ile ilgili etkili bir alan olduğu sonucuna varılabilir.

Aile hayatında dair paylaşımla karşılaşan K16: “...böyle işte şey falan yazıyorlar. Kadın kocasının geldiğinde paltosunu çıarmalı işte Müslüman bir kadın kocasının yanında güzel giyinmeli, Müslüman bir kadın 
evde dışarda olduğundan daha güzel olmalı işte kocasına hizmet etmeli, kocasına ilgi göstermeli falan filan gibi böyle şeyler yazıyor..." şeklinde bunu belirtmiştir. Aile hayatıyla ilgili olarak katılımc1 K2: "Mesela kadınların işte neden kapanması gerektiğiyle ilgili. Mesela insanların bir sürü yorumu var." sözlerini dile getirmiştir.

Erdoğan'ın çalışmasındaki Müslüman kadın algısı ile katılımcıların sosyal medyada karşılaştıkları Müslüman kadın imajı benzerlik göstermektedir. ${ }^{27}$ Özkan'ın çalışması ile katılımcıların din ve kültür üzerine olan algılarının benzerlik gösterdiği sonucuna ulaşılmıştır. ${ }^{28}$ Ayrıca Akgün'ün çalışmasındaki yeni tip muhafazakârlık şekli ile katılımcıların bazılarının sosyal medyadaki muhafazakârlara yönelik düşüncelerinin benzerlik gösterdiğini söylenebilir. Bu benzerlik günümüz yaşantısına uyum sağlamaya yöneliktir. ${ }^{29}$

\subsubsection{Din ile İlgili Yorumlar}

Sosyal medya bireylerin fikirlerini yorum yoluyla özgürce belirtebildikleri bir mecradır. Ancak paylaşımlarla ilgisi olmayan yorumların varlığı da söz konusudur. Katılımcı K3: “...hani hiç böyle açıkçası direkt olarak dinle alakalı bir gönderiye denk gelmedim ama... bence bu biraz bizim ülkemizle alakalı, yaşanan her olay aslında bir noktada dinle ilgili yorumlanıyor... mesela trafik kazasında bile işin sonu bazen dine ulaşabiliyor. En çok dine maruz kaldığım alan da o oluyor sosyal medya üzerinden." sözleriyle benzer durumu dile getirmiştir. Katılımcılardan K1: "Benim din içerikli paylaşımlardan ziyade mesela paylaşımların din üzerine yorumlanmaya böyle çekildiği yorumlarla karşılaştığım oluyor." ifadesi ile belirtmiş ve buna örnek olarak "Bir şey atılmış bir hayvan videosu, biri yazmış ki yüce Rabbim ne güzel yaratmış, hemen onun altında satırlarca biri diyor 'Allah yok!', biri diyor 'hayır var kardeşim' falan öyle, bunlarla denk geliyorum daha çok." sözleriyle belirtmiştir.

Güneş'in din ile ilgili yorumlara yönelik çalışması katılım grubundan ulaşılan sonuçlar ile benzerlik göstermektedir. ${ }^{30} \mathrm{Bu}$ benzerlik din ile ilgili olsun olmasın herhangi bir konunun din ile yorumlanması noktasındadır. Ancak Güneş'in çalışmasında farklı inançlar tarafından dine yönelik bu

${ }^{27}$ Halide Erdoğan, “İslamofobi Bağlamında Müslüman Kadın İmgesi”, AïBÜ illahiyat Fakültesi Dergisi 7/14 (2019), 637-651.

${ }^{28}$ Fatih Özkan, "Dinin Anlaşılmasında Kültürel Etki”, Iğdır Üniversitesi Sosyal Bilimler Dergisi 10 (Ekim 2016), 304-312.

${ }^{29}$ Eda Akgün, "Sosyal Medya Platformlarından Youtube Üzerinden Benlik Sunumunun Dramaturjik Bir Analizi", Yeni Medya 15 (2018), 36-47.

30 Abdurrahman Güneş, "Medyanın Olumsuz Din Algısına Etkisi”, Firat Üniversitesi Sosyal Bilimler Dergisi 28/1 (Ocak 2018), 214. 
yorumlar yapılırken; katılımcıların görüşlerinden ulaşılan sonuçta herhangi bir konunun Allah veya İslam ile ilişkilendirilmesi kendi ülkelerinin vatandaşları tarafından yapılmaktadır. Ayrıca Güler'in çalışmasında sosyal medyanın din alanında uzman olmayan kişiler tarafından bilgisizce yorum üretip paylaşım yapabildikleri bir mecradır. Bu yönüyle katılımc1ların herkesin herhangi bir konuda dini kullanıp yorum yapması bu çalışma ile benzerlik göstermektedir. ${ }^{31}$ Sosyal medyanın kontrol edilemez bir bilgi içeriğine sahip olması inanç ile ilgili konularda bireyler tarafından yapılan paylaşımlar ve yorumlarda da kendini göstermektedir. Bu noktada bilgi kirliliğinin önüne geçebilmek için kullanıcıların sosyal platformlarda karşılaştıkları içeriği kontrol edebilecekleri kaynaklara ihtiyaç duydukları söylenebilir.

\subsection{Dinî İçeriğin Niteliği ile İlgili Bulgular}

Katılımcıların sosyal medyada karşılaşılan dini içeriğin niteliğgi ile ilgili görüşleri; ötekileştirici, çelişkili, yanlış yönlendirici ve yüceltici temaları altında toplanmıştır.

\subsection{1. Ötekileștirici}

Katılımcılar sosyal medyada karşılaşılan içeriklerin farklı olan birey, tutum, düşünce ya da davranışlara dönük ayrıştırıcı yapılara sahip olmasinı vurgulamaktadırlar. Bu durumu katılımcı K7: "Bence toplum... direkt zıtlaştırılıyor çünkü gördüğüm fikirler ya şey fikirleri çok kötülüyor ya da dini yüceltiyor diğerlerini ötekileştiriyor kafir diyor... hep gördüğüm fikirler karşı tarafı ezmek şeyi içinde, çok şey görmüyorum tarafsız." şeklinde belirtmiştir. Benzer durumu katılımcı K19: "Bir taraf dini olduğu için yargılıyor bir taraf dini olmadığı için yargılıyor. İki tarafın arasında böyle bakıp duruyorum kavga ediyorlar sürekli. Bir taraf böyle başı kapalı olduğu için yaptığını yargılıyor, bir taraf başı açık olduğu için yaptığını yargılıyor." şeklinde ifade etmiştir. Katılımcı K5: "Diyelim ki bunu Hristiyanlık dinine inanan insanlar yapmış, hemen onlarla ilgili bir ayrışım oluyor." ve "İslam dinine karşı olan bir algı var ya hani? Gerek yurtdışında olsun gerek hani ülkemizde olup İslam dinine inanmayıp, ülkemizde İslam dinini, inananları küçümseyen insanları falan görünce açıkçası sinirleniyorum." şeklinde belirtmiştir.

Sosyal medyada ötekileştiriciliğin oluşturduğu toplumsal yapıyı katılımcı K4: “...O yüzden kutuplaşmalar daha yaygınlaşmaya başlıyor ya da

31 İlhami Güler, "Sosyal Medyada Din”, Medya ve Din Tartışmaları Sempozyum Bildirileri”, (İstanbul: İstanbul Ticaret Üniversitesi, 2018), 230-232. 
daha ırkçılık artıyor." şeklinde belirtmiştir. Katılımcı K22: "Ya din konusunda insanları çok fazla ayrıştırıyorlar. Aslında tam olarak ortak noktamız olması gereken bir şey. Ama mesela dini kullanan çok fazla kişiler ve kurumlar olduğu için..." şeklinde belirtmiştir.

Müslüman kadının giyimi ile ilgili olarak katılımcı K11: “...Genellikle haberler izlerken yani böyle dehşet şekilde kapalı insanlara karşı bir dalga geçerlilik var yani. Kötü niyet, önyargı." şeklinde ifade etmiştir. Tesettürün ötekileştirilmesini katılımc1 K14: “... genel olarak hep böyle mesela türbanlı, kapalı kadınlarla alakalı. Hep böyle dalgaya vurma merakı var.” şeklinde ifade etmiştir.

Menekşse'nin ${ }^{32}$ çalışmasında, yabancı ülkelerde medyanın İslam'a yönelik haberlerde çoğunlukla tarafsız ve objektif olmadığı belirtilmiştir. Katılımcıların görüşlerinin bu çalışmayla benzerliği; İslam dininin kötü yansıtılmasıdır. Ancak bu iki çalışma katılımcıların Müslüman kimliğine sahip bireylerin Müslümanlığı ve Müslümanları kötü göstermesi ve daha katı olan başka dinlere rağmen o dinlere karşı ötekileştirme görülmemesi yönünden farklıdır. Ayrıca ötekileştirmenin Müslümanlar tarafından başkalarına yapıldığı sonucuna da ulaşılmaktadır. Alan yazında da giyim kuşam ve yaşam tarzına dönük ötekileștirmenin ${ }^{33}$ ve bunların kutuplaştırıcı bir etkiye sahip olmasının ${ }^{34}$ ele alındığı çalışmalar mevcuttur.

Sosyal medyanın kullanıcıların kimliğini gizleme seçeneği sunması ötekileştirme ve buna bağlı nefret söyleminin de önünü açmaktadır. Ötekileştirme ve nefret söylemine maruz kalan bireylerin haksız bir şekilde itham edilmesi ve kendilerini açılama imkânından mahrum olmaları ise toplumsal bütünleşmenin önünde bir engel olarak yer almaktadır.

Sosyal medyada karşılaşılan paylaşımlarda tikel bir durum üzerinden genellemeler yapılmasının da ötekileştirmeye yol açabileceği ile ilgili sonuçlara ulaşılmıştır. Katılımcı K2: “...Veya yine herhangi bir şey hayvanlarla ilgili bir şey olsun veya hani cinayet haberi olsun, tecavüz haberi olsun gene hani dini kullanarak mesela işte yapan kişi Müslümansa direkt Müslümanlığa hani laf gelebiliyor, eleştiri gelebiliyor." şeklinde yaşanan olumsuzluğun genele yansıtıldığını belirtmiştir. Sosyal medyada karşılaşılan dinî içerikler olumsuz bir algıya neden olabilmektedir. Katılımcı K5:

32 Ömer Menekşe, “Türk Sinemasında Din ve Din Adamı İmajı”, II. Uluslararası Dini Yayınlar Kongresi, (Ankara: Diyanet İşleri Başkanlığı Yayınları, 2005), 45-68.

33 İbrahim Tozlu, "Sosyal Medya Hadis Paylaşımlarında Tekfir Problemi", Sosyal Bilimler Dergisi 21 (Mart 2018), 98-116.

${ }^{34}$ Şebnem Özdemir, "Sosyal Medyada Etik”, Sosyal Medya Psikolojisi, ed. Gül Dilek Türk - Şebnem Özdemir (Ankara: Nobel, 2020), 1-280. 
“...hani sosyal medyanın genelinde yani veya diyelim ki bazı terör örgütleri yapmış. Hemen Müslümanlıkla ilgili öyle yani genel olarak yaşadığımız kötü olayların hepsini belli bir dine sürekli ötelemeye çalışıyormuşuz gibi." şeklinde bu durumu belirtmiştir.

Özellikle din ve dindar insanlarla ilgili olumsuz genellemeler İslamofobinin temellerini oluşturmaktadır. Olumsuz genellemeler ötekileştirmenin ve toplumsal bütünlüğün bozulmasının da önünü açmaktadır. Güneş'in çalışması da benzer bir şekilde İslam ile ilgili medyada yer alan olumsuz içeriklerin bireylerin bakış açılarını etkilediğini ortaya koymaktadır. ${ }^{35}$ Sosyal medya gibi geniş kitlelere kolayca ulaşabilen kanallarda yer alan ötekileștirici ifadeler kullanıcılarda olumsuz algı ve tutumların oluşmasını ve bunların kalıcı bir şekilde yerleşmesini beraberinde getirmektedir. Bu noktada ötekileştirici içeriklerin yıkıc1 etkisi ile mücadele edebilmek için doğru bilginin yayılımının desteklenmesi gerekmektedir.

\subsection{2. Çelişkili}

Belli bir konu ile ilgili birbiriyle çelişen bilgilere ulaşmak ya da bireyin söz ve davranışları arasındaki çelişkinin varlığı katılımcıların karşılaştığı önemli bir problem olarak görülmektedir. Katılımcılardan K20: “...Bunları gerçekten teyit etme amacı duydum normalde geçerim hani ilgilenmem. Ama bakıyorum ve bazıları gerçekten çok çelişkili oluyor. Doğru da çıkmıyorlar." sözleriyle bilgi alanındaki çelişkiyi belirtmiştir. Katılımcilardan K1; “...mesela Müslüman olduğunu iddia eden insanların hiçbir Müslümana yakışmayacak hareketler yaptığı falan oluyor. Sosyal medyada bunları yayınlıyor." sözleriyle inanç ve davranıştaki çelişkiyi dile getirmiştir.

Sosyal medyada var olan bilgilerin kaynağının belli olmaması, sosyal medya kullanıcılarının eylemleri ile sosyal medyadaki din içerikli paylaşımın çelişkili olabilmesi ve bilgilerin teyit edilebileceği bir mekânizmanın bulunmaması kullanıcıları bir tür karmaşaya sürüklemektedir. Sütlüoğlu'nun çalışması ile katılımcıların görüşleri gerçek hayattaki ve sanal ortamlardaki kimlik farklılıklarının varlı̆̆ı açısından benzerlik göstermektedir. ${ }^{36}$ Katılımcıların karşı karşıya kalmış oldukları çelişkili bilgi akışı ya da ifadeleri tespit etmeleri dijital ortamda yer alan bilgilerin güvenirliği ile ilgili şüphelerin kaynağı olmaktadır.

35 Abdurrahman Güneş, "Medyanın Olumsuz Din Algısına Etkisi”, 213-214.

${ }^{36}$ Tuba Sütlüoğlu, "Sosyal Paylaşım Ağlarında Gençlerin Sosyalleşme ve Kimlik İnşası Süreçleri: Facebook Örneği”, Folklor/Edebiyat 21/83 (2015), 125-147. 


\subsubsection{Yanlı̧ Yönlendirici}

Sosyal medya kanallarında yer alan bilgilerin kullanıcılar tarafindan manipüle edilerek belli bir amaca göre yönlendirici bir biçimde kullanılması katılımcıların tespit ettiği bir başka problemdir. Bir yorumun çıkarlara hizmet edebildiği görüşünü katılımc1 K1: “... o bilgiyi paylaşan kişi mesela iyi niyet ya da kötü niyetli fark etmez, bunu genellikle araştırmadan yapıyor ki onun dışında kötü niyetli olarak atılan sözler de olabiliyor... mesela yanlış yorumlanmış atıyorum Kur'an-1 Kerim'den bir ayet, o yorumun yanlış olması işine gelen insanlar hemen bunu yapmak istiyor." sözleriyle belirtmiştir. Katılımcılardan K4: “dinle ilgili kendi fikirlerini beğenenler, genelde fikrini beğendikleri için, sanki kesin öyle gibi anlattığı için insanlar direkt ona inanabiliyor." diye ifade etmiştir.

Sosyal medyadaki dini içerikler yönelik olarak katılımc1 K7: “...çok çarpıtılan şeyler oluyor bu yüzden.” şeklinde ifade etmiştir. Sosyal medyadaki dinî içeriklerin yanlış anlatılmasından kaynaklı davranışlar hakkındaki düşüncelerini katılımcılardan K9: “...Yaptıkları yorumlar ve yaptı̆̆ı şeyler mesela insanların işte din kapanın diyor ama onu yanlış anlatan insanlara göre bilerek açılıyorlar.” sözleriyle ifade etmiştir. “...işte mesela kadına şiddeti örnek vereyim... Bunu kötüye kullanan kadınlar var ve en önemlisi dinin söylediği şey şu mesela diyor ki kadınları hoş görün. Kadınlar sizden bir parçanız onlar da insanlar çocuklar gibi erkekler gibi onların hiçbir farkı yok. Onları koruyup gözetmeniz onları yüceltmeniz gerekiyor diyor ama insanlar da dini yanlış anlattıkları için de onlara karşı bir şey oluşmuş eskiden, sonrasında da sırf bunu yapmamak için tersine psikoloji uyguluyorlar ve feminizmin feminaziliğe dönüşen bir formuyla karşılaş1yoruz." şeklinde ifade etmiştir.

Kiraz'ın çalışmasındaki sosyal medyada bireylerin farkında olmadan manipülasyona ve sahte haber yayılımına etkisi düşüncesi ile katılımcıların görüşleri üzerinden benzer sonuca ulaşılmıştır. ${ }^{37}$ Dinin kaynağı Kur'an'ın kasti olarak veya olmayarak yanlış yorumlanmasının yanlış yönlendirmeye etkisi de ulaşılan sonuçlardandır. Yanlış yönlendirici nitelikteki içeriğin birtakım kötü niyetli kişiler tarafından çıkar amaçlı kullanıldı̆̆ı sonucu ile Tiyek'in çalışması benzerlik göstermektedir. ${ }^{38}$ Ayrıca dinîn emir ve yasaklarını yanlış anlamanın, bireyler açısından dini yanlış yaşamaya yönlendirebileceğini söylemek de mümkündür.

${ }^{37}$ Ersel Kiraz, “Sosyal Medyada Sahte Haberin Yayılmasında Kullanıc1 Faktörü”, INIFF E-DERGI 5/1 (May1s 2020), 18.

${ }^{38}$ Fatih Tiyek, "Sosyal Medyadaki Ayet Paylaşımlarında Dikkat Edilmesi Gereken Hususlar (16 Nisan 2017 Referandumu Bağlamında)”, Kahramanmaraş Sütçü İmam Üniversitesi İlahiyat Fakültesi Dergisi 30 (Aralık 2017), 362-363. 


\subsection{Dinî İçeriğin Din Kültürü ve Ahlak Bilgisine Yansımasına İlişkin Bulgular}

Katılımcılar sosyal medyada edindikleri bilgilerin Din Kültürü ve Ahlak Bilgisi dersine dönük yansımalarının olumlu ve olumsuz yönde olabildiğini vurgulamaktadırlar. Katılımcılardan K4: "Bu tür şeylerin dersin akışını çok etkilediğini düşünmüyorum. Zaten dersin akışını etkilemesi için ya da dersi etkilemesi için genel olarak öğrenciden ziyade öğretmeni etkilemesi lazım. Ki zaten öğretmenlerin de genel olarak kendi fikirleri, kendi prensipleri olduğu için kolay kolay etkilenmiyorlar. Sadece kendilerine göre bazen yanlış gördükleri şeyi bize açıklamak istiyorlar sosyal medyada. Bunun dışında çok bir etkisi olduğunu hiç sanmıyorum." sözleriyle düşüncelerini dile getirmiştir. Bunun aksine katılımcı K1: "Yani bazen sosyal medyadaki din ile ilgili yalan yanlış bilgiler bir öğrencinin aklına takıldığında o da haliyle Din Kültürü ve Ahlak Bilgisi öğretmenine sorabiliyor. Yani bunun sonucu olarak da bazen iște o yanlış bilgiler diğer öğrencilerin kafasında yer edinebiliyor ya da öğretmen bu bilgiyi düzeltirken vakit kaybı yaşanabiliyor ama onun haricinde çok bir etkisi olduğunu düşünmüyorum.” şeklinde düşüncelerini belirtmiştir.

Sosyal medyadaki din içerikli paylaşımların derse yansımasını katılımcı K6: “...Öğretmenlerimizin ben hani şahsen sosyal medyadaki dinî içeriklerden etkilendiğini görmedim. Ya da hani bunlarla alakalı çok fazla konuştuklarını da görmedim... din dersinde tabii hocayla öğrenci arasında sohbet geçerken hani öğrencilerin etkilendiği oluyor. Ama bunun üzerinden hani maksimum diyebileceğim öğrencilerin hani sosyal medyada kendi dini kimliklerini keşfetmesi veya dini kimlikleriyle alakalı gelişmeler yaşanmasından ötürü hani hocayla konuşmalarında bunlar yansıyabiliyor. Atıyorum hani öğrencinin inancı değişebiliyor ya da hani inancı farkliysa bile bununla alakalı cesaret kazanabiliyor ve derste bununla alakalı daha rahat konuşabiliyor öğretmenle. Ya da hani karşıt bir fikir edinip derste bu karşıt fikri de belirtebiliyor. Onu geçtim internet üzerinden başka insanların argümanlarını dinleyip o argümanları kendisi de benimsedikten sonra bunları din dersinde hocaya da sunabiliyor." şeklinde ifade etmiştir.

Sosyal medyada ile Din Kültürü ve Ahlak Bilgisi dersinde görülen dini bilginin farklılık gösterdiğini ve bu farklılığın kaynağını katılımcılardan K8: “...O dini içerikli görseller çoğunlukla böyle insanlara burada zulüm var buna yok mesela bu insanlara yardım edin. İşte fakirlik var dayanışmayı artırın. Ne bileyim işte bakın burada zulüm oluyor sessiz kalmayın gibi mesajlar verirken Din Kültürü ve Ahlak Bilgisi bunları yapıyor ama bunları yaparken Kur'an-1 Kerim'i temel alıyor. Hz. Muhammed'in sözle- 
rini temel alıyor. Ondan sonra uzman görüşlerini alıyor. Genel olarak hani bilim adamlarının akademisyenlerin görüşlerini ele alıyor. Bu yüzden aslında dini içerikli görseller internette gördüğümüz dini içerikli görseller pek böyle Din Kültürü ve Ahlak Bilgisi dersinin önemini artırmaktan ziyade orada işte zaten belli bir yaş grubuna hitap ediyor. Takdir edersiniz ki pek böyle gençlere hitap eden görseller olmuyor çoğunlukla. $O$ yüzden hani onlar daha çok böyle işte siz Allah'a kulluk edin, devam edin... Biraz daha böyle kısa mesajlar yani küçük mesajlar vermek adına ama işte Din Kültürü ve Ahlak Bilgisi müfredatı Millî Eğitim Bakanlığı'nın hazırlamış olduğu müfredat biraz daha işin teknik kısmına dayanıyor. İbadet nasil yapılır? İște ondan sonra farz olan ibadetler nelerdir? Ne bileyim işte İslamiyet'i tanıtan bir sürü aslında bir içerik silsilesine sahip. Ya bu yüzden benim bakış açımı aslında somut olarak etkilemiyor." sözleriyle belirtmiştir.

Sosyal medyadaki dini içeriklerin din algisına olumsuz etki edebilmesi sebebiyle bu durumun din dersine bakışı değiştirebileceğini katılımcılardan K3: "Şu anda sosyal medya üzerinden direkt olarak din olgusu hakkında olumsuz bir algı yayılıyor. Tabii ki bunun bence din derslerine de etkisi var. Çünkü hani bazı öğrenciler hani din konusunda eğer ki olumsuz fikirlere sahiplerse Din dersi görmenin de onlara böyle bir dayatma olarak gösterildiğini düşünüyor olabilirler. Bu da tabi onları ders hakkında olumsuz etkileyebilir. Yani derse odaklanmama şey gibi. Ama tabi üniversite sınavinda vesairede din dersinden sorumlu oldukları için bazen zorla hani çalışma gibi bir durum oluyor. Bu da onları dinden daha da uzaklaştırabilir bence. Eğer sosyal medyada din konusunu ilgilendiren bir olay gündem olduysa vesaire bunlar bizim derslerimizde de konuya yansıyordu, üzerinde konuşuluyordu. Özellikle evlilik, boşanma gibi meselelerde açıkçası ben çokça hani dini tartışmalar yaptığımızı hatırlıyorum. Yani tabi ki inanmak inanmamak ya da yapılan kara mizah adı altında yapılan şeylerden de bazen bahsedildiği oluyor. Onların işte hani mizah olup olmadığı ya da ne kadar doğru olup olmadığı tartışılıyor. Yani ben şahsen açıkçası yani sosyal medyada gördüğüm şeyleri hani derste böyle konuşma taraftarı değilim. Çünkü sosyal medyadaki insanların neyi ne amaçla yaptığı ya da kendi düşüncelerinin ne olduğu belli olamayabiliyor. Ya da kendi düşüncelerinin ne olduğunun dışında sosyal medyada nasıl yansıtmaya çalıştıkları da belli olmayabiliyor. Yani bu yüzden ben çok böyle yansıtmamaya çalışıyorum ama sosyal medyadaki içeriklerin derse yansıdığı bir gerçek bence." şeklinde belirtmiştir.

Sosyal medyanın etkisi altında kalan alanlardan biri olan din ve buna bağlı olarak Din Kültürü ve Ahlak Bilgisi derslerinin de şekillenmesi ger- 
çeği ile karşılaşılmaktadır. Arpacı'nın çalışmasında değerler eğitiminde hadis ve ayetlerden faydalanmanın Din Kültürü ve Ahlak Bilgisi dersi açısından önemine değinilmiștir. ${ }^{39}$ Katılımcılar da öğretmenlerinin derslerde ayet ve hadisi temel alan yaklaşımlarından söz etmişlerdir. Değerlerin sosyal medyada ve Din Kültürü ve Ahlak Bilgisi dersinde bulunuşuna yönelik görüşler de benzerlik göstermektedir. Öğretmenlerinin derste kullandıkları kaynaklar ile sosyal medyadaki dinî içeriklerin kaynaklarının farklılığı nedeniyle sosyal medyadaki din ile ilgili paylaşımların dersin işlenişine etkide bulunmadığı sonucuna ulaşılmıştır. Nazıroğlu'nun çalışması ile katılımcıların görüşleri tutarlılık göstermektedir. Bu çalışmada bir mesajın her birey tarafından farklı algılanabileceği ve bunun da etkilerinin olabileceğinden söz edilmektedir. Kişisel deneyimlere bağlı olarak birey algıladığı mesajın içinde kalır ve bu da bireyin kabullerini şekillendirir. Kabullenilen veya reddedilen mesajlar sonucu birey bunu yaşamın okul, aile, sosyal alan gibi çeşitli alanlarına yansıtır. ${ }^{40}$

Katılımcılardan bazılarının sosyal medyada karşılaşılan dini içerikleri ders ortamına taşımadıkları görülmektedir. Sosyal medya içeriklerini ders ortamında tartışan katılımcıların ise; bilgileri teyit etme, dini bilgilerini artırma ve farklı görüşleri anlamaya çalışma gibi noktaları vurguladıkları görülmektedir. Din Kültürü ve Ahlak Bilgisi dersi içeriği gereği katılımcıların sosyal medyada yer alan dini paylaşımları konuşabilecekleri bir zemin sunmaktadır. Bu noktada Din Kültürü ve Ahlak Bilgisi dersi sosyal medyadaki bilgi kirliliğinin olumsuz etkilerinin en aza indirebileceği bir imkân olarak değerlendirilebilir.

\section{Sonuç ve Öneriler}

Günümüz teknoloji çağında bireylere din eğitiminin verilmesi geçmiş dönemlere kıyasla çok daha karmaşık ve zor bir hal almıştır. Bu duruma neden olan unsurlardan biri dinî bilgiyle karşılaşılan ve dinin öğrenildiği kaynaklardaki meydana gelen artıştır. Sosyal medyada dini içeriklerin sunumu giderek popülerleşmekte ve bu durum ise dini bilgide yozlaşmaya ve özünden uzaklaşmaya neden olabilmektedir. Din eğitiminin toplumun her kesiminden bireyin en doğru dini bilgiye ulaşabileceği bir firsat olabilmesi için sosyal medya gibi alanların eğitim üzerindeki etkileri gözden kaçırılmamalıdır.

Bu çalışmada 12. sınıf öğrencilerinin sosyal medyada karşılaştıkları

39 Mücahit Arpacı, "Din Kültürü ve Ahlak Bilgisi Öğretmen Adaylarının Değer ve Değerler Eğitimine İlişkin Görüşleri”, Dinbilimleri Akademik Araştırma Dergisi 13/2 (2013), 222-227.

40 Bayram Ali Nazıroğlu, "Din Eğitiminin Gerekliliği Açısından Dini Medya Okuryazarlığı”, Dinbilimleri Akademik Araştırma Dergisi 15/2 (2015), 213-218. 
dinî içerikler, dinî içeriklerin nitelikleri ve bunların Din Kültürü ve Ahlak Bilgisi dersine yansımaları değerlendirilmiştir. Sosyal medyanın bireysel ve toplumsal hayattaki din algısını şekillendiren önemli bir etken olduğu anlaşılmıştır. Sosyal medyada bulunan din ile ilgili içeriklerin çeşitlilik göstermesi ile birlikte dinle bağı olmayan paylaşımların da sosyal medyada dini çerçevede değerlendirildiği sonucuna ulaşılmıştır. Sosyal medyada bulunan din içerikli paylaşımlar 12. sınıf öğrencilerinin genelinde olumsuz algıya sebep olmaktadır. Bu olumsuz algının sebebine bakıldığında ise ötekileştirici tavrın etkili olduğunu söylemek mümkündür. Elde edilen bulgular üzerinden, toplumdaki bireylerin farklı inanç, yaşam ve giyim tarzı ve felsefi görüş gibi nedenlerle sosyal medyada ötekileştirilmelerinin din anlayışına dönük bakış açısına zarar verdiği sonucuna ulaşılmıştır. 12. sınıf öğrencilerinden elde edilen bulgulardan, toplumdaki bireylerin birbirlerinin özel yaşamlarındaki tercihlerinde olan farklılıkları anlayışla karşılamadıkları ve bu durumun sosyal medyada insan haklarının ihlalini gündeme getirdiği sonucuna ulaşılmıştır. Bu hakların ihlali ahlaki değerlere de ters düşmektedir. Bu açıdan bakıldığında sosyal medyadaki bazı içeriklerin ahlaki ilke ve değerleri olumsuz şekilde etkilediği sonucuna ulaşlabilir.

12. sınıf öğrencilerinin sosyal medyada karşılaştıkları dinî içeriklerin Din Kültürü ve Ahlak Bilgisi derslerine yaklaşımlarını olumlu ve olumsuz yönde etkileyebildiği sonucuna ulaşılmıştır. Ayrıca Din Kültürü ve Ahlak Bilgisi dersinde öğretmenin konuları dinin ana kaynaklarını temel alarak açılamasının 12. sınıf öğrencilerinin sosyal medyada karşılaştıkları içeriklerin güvenilirliğini daha kolay tespit ettikleri söylenebilir. Bu noktada derste ele güvenilir bilgi kaynakları aracılığıyla yapılan açıklamaların sosyal medya aracılığıyla edinilen yanlış ya da yanlı bilgilerle mücadelede önemli olduğu sonucuna varılabilir.

Tüm yaş grubundan öğrenciler sosyal medyada karşılaştığı dinî içerik karşısında dinin temel kaynaklarından faydalanmalıdır. Dijital ortamlarda karşılaşılan bilgilerin teyit edilebileceği mekanizmaların oluşturulabilmesi bu noktada önemli bir adım olacaktır. Sosyal medya kullanıcılarının günlük yaşamdaki ahlaki değerleri dijital ortama taşıyabilmeleri ve kaynağı belli olmayan bilgilere şüpheyle yaklaşılmaları sağlıklı bir iletişim için gereklidir. Öğrencilerin derse yaklaşımlarında sosyal medyanın etkisi dikkate alınmalı ve Din Kültürü ve Ahlak Bilgisi ders kitaplarında sosyal medyada yer alan dinî içeriklerin değerlendirilmesi gibi güncel konulara da yer verilmelidir.

Dijital ortam kullanımının sosyal yaşamın vazgeçilmez bir parçası olması bu ortamların eğitim öğretim süreçlerini etkilemesini de kaçınılmaz 
kılmaktadır. Çocuk ve gençlerin sosyal medyayı sosyalleşmenin yanında birer bilgi kaynağı olarak kullanmaları ve özellikle Covid19 salgınıla birlikte dijital ortamların mecburi bir öğrenme ve ötekiyle iletişim kurma alanı haline dönüşmesi bu platformlardaki bilgilerin öğrenme ortamları üzerindeki etkilerini eğitimsel açıdan düşünmeyi de gerekli hale getirmektedir. Kontrolsüz bir bilgi alanı olan dijital ortamlar; yanlış, ötekileştirici ya da eksik bilginin kolayca yayılabildiği alanlar olabileceği gibi bilgiye erişimin kolaylığı ve dijital öğrenmeye mecbur olunan dönemlerde sosyalleşmenin yegâne aracı olarak bireylerin yaşamına büyük bir kolaylık getirmekte ve dünyalarını genişletmektedir. Bu noktada eğitim öğretim içeriklerine bireylerin dijital okuryazarlık becerisini destekleyecek amaçlar ve kazanımlar eklemek hangi bilginin nasıl değerlendirilebileceği ile ilgili bir farkındalık yaratacaktır.

\section{Kaynakça}

Akgün, Eda. "Sosyal Medya Platformlarından Youtube Üzerinden Benlik

Sunumunun Dramaturjik Bir Analizi”. Yeni Medya 15 (2018), 29-49.

Akıncı, Vural, Z. Beril - Bat, Mikail. "Yeni Bir İletişim Ortamı Olarak Sosyal Medya:

Ege Üniversitesi İletişim Fakültesine Yönelik Bir Araştırma”. Journal of Yasar University 5/20 (2010), 3348-3382.

Arpacı, Mücahit. "Din Kültürü ve Ahlak Bilgisi Öğretmen Adaylarının Değer ve

Değerler Eğitimine İlişkin Görüşleri”. Dinbilimleri Akademik Araștırma Dergisi 13/2 (2013), 205-228.

Ayaydın, Yakup - Ayaydın, Yıldız, Hatice. "Sosyal Medyanın Değer Oluşturma

Sürecindeki Rolünün Öğrenci Görüşleriyle İncelenmesi”. Değerler Eğitimi Dergisi 16/35 (Haziran 2018), 57-89.

Bilgin, Nuri. Sosyal Bilimlerde İçerik Analizi Teknikler ve Örnek Çalışmalar. Ankara: Siyasal Kitabevi, 2006.

Boyd, Danah - Ellison, Nichole B. "Social Network Sites: Definition,History, and Scholarship". Journal of Computer-Mediated Communication 13 (2008), 210-230. Erdoğan, Halide. "İslamofobi Bağlamında Müslüman Kadın İmgesi”. AiBÜ Illahiyat Fakültesi Dergisi 7/14 (2019), 637-651. https://doi.org/10.33931/abuifd.633354 Eren, Şişman, Esra. "Sosyal Medya Kullanım Amaçları Ölçeğinin Geliştirilmesi ve Bazı Kişisel Değişkenlere Göre İncelenmesi”. Hacettepe Üniversitesi Eğitim Fakültesi Dergisi 29/4 (2014), 230-243.

Furat, Ayşe Zişan. "Din Eğitimi Ekseninde Türkiye'de Medya ve Din Araştırmaları". Medya ve Din Araștırmaları Dergisi 2/1 (Haziran 2019), 29-51.

Gezginci, Gamze - Işıkll, Şevki. “Dindar Facebook Etkisi: Türk Kullanıcılar Üzerine Bir Analiz". Medya ve Din Araștrrmaları Dergisi 1/1 (2018), 111-133.

Glesne, Corrine. Nitel Araştırmaya Giriş, çev. Ali Ersoy - Pelin Yalçınoğlu. Ankara: 
Anı Yayıncılık, 9. Basım, 2012.

Gül, Recep Emin. “Sosyal Medyada Hadis Kullanımı - Facebook ve Twitter Özelinde

-“. Yüzüncü Yıl Üniversitesi Sosyal Bilimler Enstitüsü Dergisi 30 (2016), 163-178.

Güler, İlhami. “Sosyal Medyada Din”. Medya ve Din Tartışmaları Sempozyum Bildirileri.

230-232. İstanbul: İstanbul Ticaret Üniversitesi, 2018.

Gümrükçüoğlu, Süleyman. "Din Eğitiminin Sosyal Medya Kullanımına Etkisi”. Ankara:

Nobel Bilimsel Eserler, 1. Basım, 2020.

Güneş, Abdurrahman. "Medyanın Olumsuz Din Algısına Etkisi”. Fırat Üniversitesi

Sosyal Bilimler Dergisi 28/1 (Ocak 2018), 203-216. https://doi.org/10.18069/

firatsbed.387896

Güz, Nurettin - Yegen, Ceren. “Ölü Canlar'dan Instagram'a: Kimlik ve Statü Sahibi

Olmanın Allomorfizmi Üzerine”. İletişim Kuram ve Araştırma Dergisi 45 (2017), 103-123.

Haberli, Mehmet. “Sosyal Medyada Dini İnanç ve Ahlaki Değerlerin Dejenerasyonu

Üzerine Bir Değerlendirme”. I. Uluslararası İnsanve Toplum Bilimleri Araştırmaları

Kongresi. 644-647. Balıkesir: Bandırma On Yedi Eylül Üniversitesi, 2018.

Kalaman, Sefer - Çelik, Fatih. "Türkiye'deki Evli Bireylerin Sosyalm Medya

Kullanımlarının Evlilikleri Üzerine Etkisi: Nitel Bir Araştırma”. Uluslararası

Toplum Araştırmaları Dergisi 13/19 (Eylül 2019), 426-453. https://doi.

org/10.26466/opus.589684

Kiraz, Ersel. "Sosyal Medyada Sahte Haberin Yayılmasında Kullanıcı Faktörü”, INIF E-DERGI 5/1 (May1s 2020), 9-24.

Koçak, Zeynep Canan. "Günümüz Yerleşik Peygamber Tasavvurunun Genç

Zihinlerde Karşılığı”. Süleyman Demirel Üniversitesi İlahiyat Fakültesi Dergisi 42 (2019), 117-134.

Konuk, Nebiye - Güntaş, Selime. "Sosyal Medya Kullanımı Eğitimi ve Bir Eğitim Aracı Olarak Sosyal Medya Kullanımı”. International Journal Entrepreneurship and Management Inquiries (Journal EMI) Dergisi 3/4 (Mart 2019), 1-25.

Marshall, Tara vd. "Attachment styles as predictors of Facebook-related jealousy and surveillance in romantic relationships". Personal Relationships 20 (2013), 1-49.

Menekşe, Ömer. “Türk Sinemasında Din ve Din Adamı İmajı”. II. Uluslararası Dini Yayınlar Kongresi. 45-68. Ankara: Diyanet İşleri Başkanlığı Yayınları, 2005.

Miles, Matthew B. - Huberman, A. Michael. Nitel Veri Analizi.çev. Sadegül Akbaba Altun - Ali Ersoy. Ankara: Pegem Akademi, 2016.

Nazıroğlu, Bayram Ali. "Din Eğitiminin Gerekliliği Açısından Dini Medya Okuryazarlığı”. Dinbilimleri Akademik Araştırma Dergisi 15/2 (2015), 191-220.

Okumuşlar, Muhittin - Genç, Fatih.” Din Eğitiminin Bilimselleşmesi/Neliği”. Din Eğitimi. ed. Recai Doğan-Remzi Ege. 53-79. Ankara: Grafiker Yayınları, 2015. Özdemir, Şebnem. "Sosyal Medyada Etik”. Sosyal Medya Psikolojisi. ed. Gül Dilek 
Türk - Şebnem Özdemir. 1-280. Ankara: Nobel, 1. Basım, 2020.

Özkan, Fatih. “Dinin Anlaşılmasında Kültürel Etki”. Iğdır Üniversitesi Sosyal Bilimler Dergisi 10 (Ekim 2016), 299-314.

Özpolat, Vahap. "Postmodern Bir Sosyalleşme Mecrası Olarak Sosyal Medya ve Gençlik”. Gençlik ve Kültürel Mirasımız. ed. Bekir Şişman - Muhittin Düzenli. Uluslararası Kongre II. 48-50. Ankara: Gençlik ve Spor Bakanlı̆̆ı, 2014.

Öztürk, Mehmet Fatih - Talas, Mustafa. "Sosyal Medya ve Eğitim Etkileşimi”. Zeitschrift für die Welt der Türken/ Journal of World of Turks 7/1 (2015), 101-120.

Parladır, Selahattin. “Din Eğitiminde Hedefler”. Dokuz Eylül Üniversitesi İlahiyat Fakültesi 9 (1995), 79-102.

Saldana, Johnny. Nitel Araştırmacılar İçin Kodlama El Kitabı, çev. Aysel Tüfekçi AkcanSüleyman Nihad Şad. Ankara: Pegem Yayınları, 3. Basım, 2019.

Sucu, İpek. "Sosyal Medya Oyunlarında Gerçeklik Olgusunun Yön Değiştirmesi: Smeet Oyunu Örneği”. Gümüşhane Üniversitesi İletişim Fakültesi Dergisi 3 (Mart 2012), 55-88. https://doi.org/10.19145/gumuscomm.98392

Sütlüoğlu, Tuba. "Sosyal Paylaşım Ağlarında Gençlerin Sosyalleşme ve Kimlik İnşası Süreçleri: Facebook Örneği”. Folklor/Edebiyat 21/83 (2015), 125-147.

Şişman, Mehmet. "Eğitim Bilimine Giriş". Ankara: Pegem Akademi 9. Basım, 2013.

Tozlu, İbrahim. "Sosyal Medya Hadis Paylaşımlarında Tekfir Problemi”. Sosyal Bilimler Dergisi 21 (Mart 2018), 98-116.

Uça Güneş, E. Pınar. “Toplumsal Değişim, Teknoloji ve Eğitim İlişkisinde Sosyal Ağların Yeri”. Açıköğretim Uygulamaları ve Araştırmaları Dergisi Eskişehir 2/2 (2016), 191-206.

Uysal, Enver. "Değerler Üzerine Bazı Düşünceler ve Bir Erdem Tasnifi Denemesi: İnsanî Erdemler-İslâmî Erdemler". Uludağ Üniversitesi İlahiyat Fakültesi 12/1 (2003), 51-69.

Tiyek, Fatih. "Sosyal Medyadaki Ayet Paylaşımlarında Dikkat Edilmesi Gereken Hususlar (16 Nisan 2017 Referandumu Bağlamında)". Kahramanmaraş Sütçü İmam Üniversitesi İlahiyat Fakültesi Dergisi 30 (Aralık 2017), 353-378.

Yağmurlu, Aslı. "Kamu Yönetiminde Halkla İlişkiler ve Sosyal Medya”. Selçuk İletişim 1/7 (2011), 5-15.

Yapıcı, Asım - Emre, Yusuf. "Mizah Anlayışı ile Dindarlığın Farklı Görüntüleri Arasındaki İlişkiler Üzerine Bir Araştırma”. Bilimname XL (Aralık 2019), 37-66. https://doi.org/10.28949/bilimname.647063

Yıldırım, Ali - Şimşek, Hasan. Sosyal Bilimlerde Nitel Araştırma Yöntemleri. Ankara: Seçkin Yayıncılık, 9. Basım, 2008. 